\title{
Electrosynthesis in Extended Channel Length, Microfluidic Electrolysis Cells
}

\author{
Robert A. Green, Richard C. D. Brown and Derek Pletcher \\ † Department of Chemistry, University of Southampton, Southampton SO17 1BJ, U.K.
}

Please cite this paper as:

J. Flow Chem.

The publisher's version of this paper is available here:

DOI: $10.1556 / 1846.2016 .00028$

Related articles by Prof Richard Brown can be found below:

1. Birkin, P. R.; Kuleshova, J.; Hill-Cousins, J. T.; Brown, R. C. D.; Pletcher, D.; Underwood, T. J., A simple and inexpensive microfluidic electrolysis cell. Electrochim. Acta 2011, 56, 4322-4326.

2. Hill-Cousins, J. T.; Kuleshova, J.; Green, R. A.; Birkin, P. R.; Pletcher, D.; Underwood, T. J.; Leach, S. G.; Brown, R. C. D., TEMPO mediated electrooxidation of primary and secondary alcohols in a microfluidic electrolytic cell. ChemSusChem 2012, 5, 326-331.

3. Kuleshova, J.; Hill-Cousins, J. T.; Birkin, P. R.; Brown, R. C. D.; Pletcher, D.; Underwood, T. J., The Methoxylation of N-Formylpyrrolidine in a Microfluidic Electrolysis Cell for Routine Synthesis. Electrochim. Acta 2012, 69, 197-202.

4. Green, R. A.; Hill-Cousins, J. T.; Brown, R. C. D.; Pletcher, D.; Leach, S. G., A voltammetric study of the 2,2,6,6-tetramethylpiperidin-1-oxyl (TEMPO) mediated oxidation of benzyl alcohol in tertbutanol/water. Electrochim. Acta 2013, 113, 550-556.

5. Green, R. A.; Brown, R. C. D.; Pletcher, D., Understanding the Performance of a Microfluidic Electrolysis Cell for Routine Organic Electrosynthesis. J. Flow Chem. 2015, 5, 31-36.

6. Green, R. A.; Pletcher, D.; Leach, S. G.; Brown, R. C. D., N-Heterocyclic Carbene-Mediated Oxidative Electrosynthesis of Esters in a Microflow Cell. Org. Lett. 2015, 17, 3290-3293.

7. Green, R. A.; .; Brown, R. C. D.; Pletcher, D.; Harji, B., A Microflow Electrolysis Cell for the Laboratory Synthesis on the multigram Scale. Org. Process, Res. Dev. 2015, 19, 1424-1427.

8. Green, R. A.; Pletcher, D.; Leach, S. G.; Brown, R. C. D., N-Heterocyclic Carbene Mediated Microfluidic Oxidative Electrosynthesis of Amides from Aldehydes. Org. Lett. 2016, 18, 1198-1201 


\title{
Electrosynthesis in Extended Channel Length Microfluidic Electrolysis Cells
}

\author{
Robert A. Green*, Richard C. D. Brown* and Derek Pletcher
}

The Department of Chemistry, University of Southampton, Southampton SO17 1 BJ, UK

\begin{abstract}
In recent papers, laboratory microfluidic electrolysis cells with extended channel lengths $(0.7$ $-2 \mathrm{~m})$ and narrow interelectrode gap $(\leq 0.5 \mathrm{~mm})$ have been introduced; these cells permit high conversions at a flow rate consistent with the synthesis of products at a rate of multigrams/hour. Such microflow electrolysis cells must be operated with appropriate control parameters if good performance is to be achieved and this paper emphasises the correct selection of cell current, flow rate and counter electrode chemistry. It is also shown that, within the limitations, the cells can be used for a number of electrosyntheses in the synthetic laboratory.
\end{abstract}

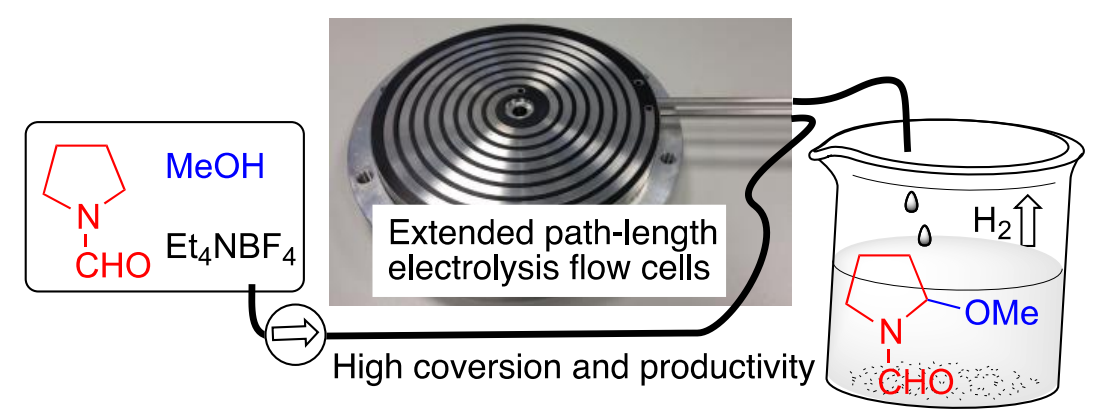

Contact: Robert A. Green and Richard C. D. Brown

rag206@soton.ac.uk

rcb1@soton.ac.uk 


\section{Introduction}

The microflow approach to organic synthesis has become popular because of its ability to deliver high selectivity and high conversions in a single pass as well as a high rate of product formation [1]. In order to play its full role in microflow synthesis, electrolysis must achieve a similar performance. This requires the design of truly novel cells recognising that in traditional beaker cells (figure 1a), the rate of conversion is very slow and a high conversion can be achieved only after many hours, and in conventional macroflow cells (figure 1b), many recycles of reactant through the cell is often unavoidable in order to reach a high conversion. A number of microflow cells have been described in the literature [2]. Often, such cells have a pathlength of only $1-3 \mathrm{~cm}$, and although the cells allow interesting chemistry, the solution flow rate is limited to $0.1 \mathrm{~mL} \mathrm{~min}^{-1}$ or less if a high conversion is to be achieved [3]. Hence, only low rates $(\mathrm{mg} / \mathrm{h})$ of product formation are possible.

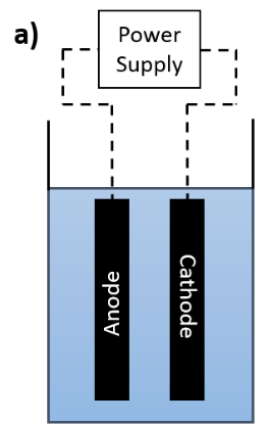

b)

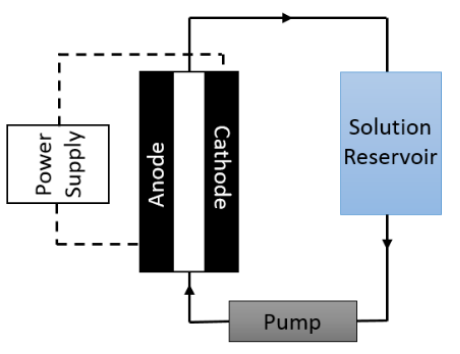

c)

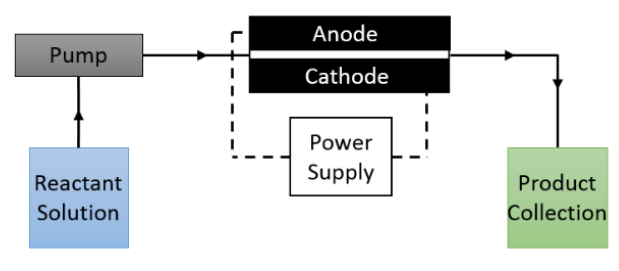

Figure 1. Schematic representations of laboratory electrolysis cells (a) beaker cell (b) flow through cell with reactant recycle (c) extended channel length microflow cell.

Recently, however, the concept of microfluidic electrolysis cells with extended channel lengths has been introduced (figure 1c). These cells are designed for convenient synthesis in the laboratory and are not aimed at large-scale commercial production. They have a channel long enough that high conversion is possible with a flow rate of $0.5-16 \mathrm{~mL} \mathrm{~min}^{-1}$ while maintaining a compact design. Two types of cells based on parallel plate electrodes with an interelectrode gap/electrolyte channel formed with a polymer spacer have been described. The cells had either

(a) a convoluted electrolyte channel with a channel length of $0.7 \mathrm{~m}$ [4] (fabricated by Syrris Ltd, Royston, UK), see figure 2(a) or

(b) a spiral electrolyte channel with a channel length of $2 \mathrm{~m}$ [5] (the Ammonite 15 cell available from Cambridge Reactor Design Ltd, Cambridge, UK). A smaller $8 \mathrm{~cm}$ diameter version (channel length of $1 \mathrm{~m}$, the Ammonite 8 cell) has now been tested, see figure 2(b). 

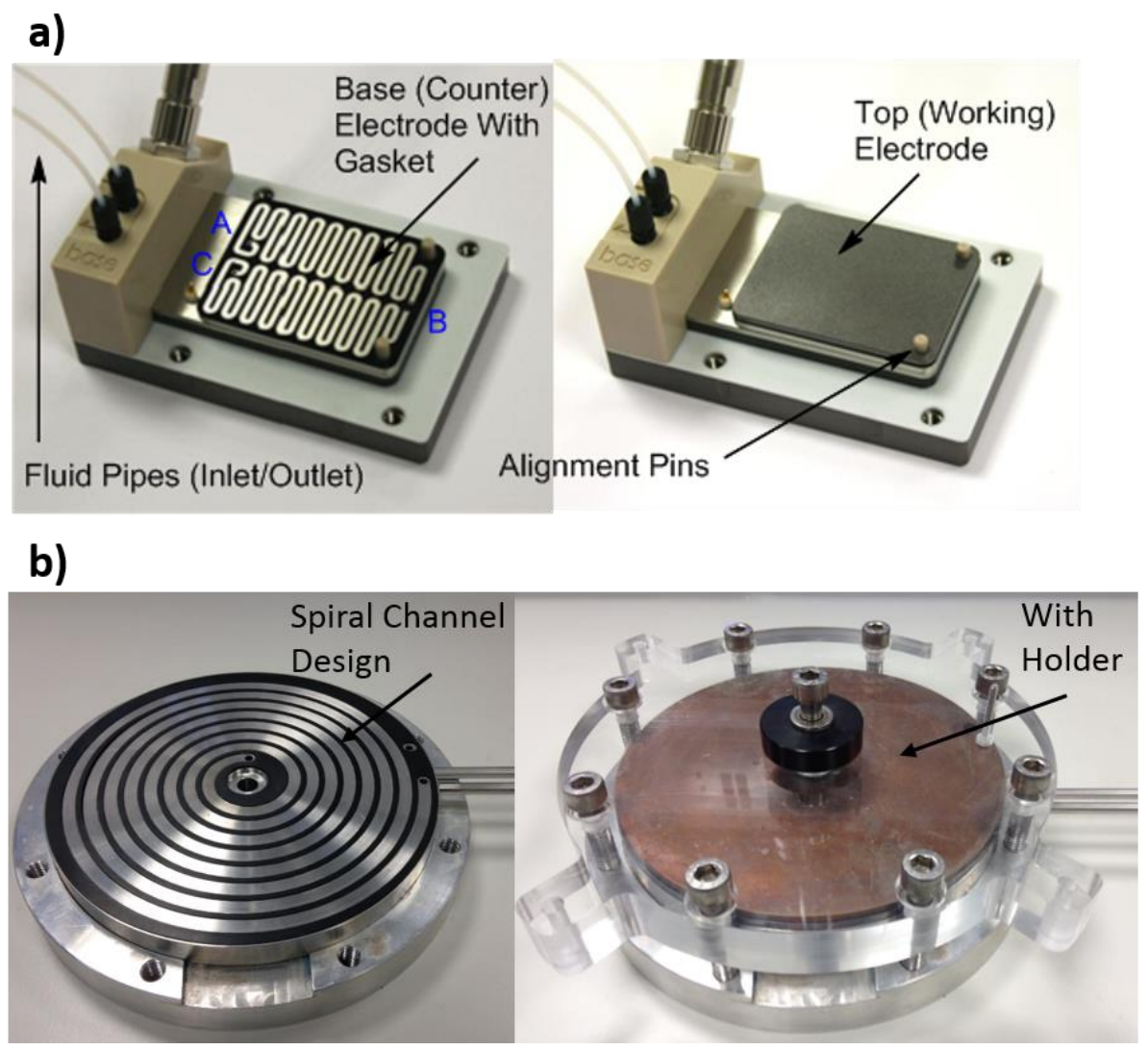

Figure 2. Extended channel length microflow electrolysis cells (a) cell with convoluted channel (Syrris) (b) cell with spiral channel (Cambridge Reactor Design).

All allow high conversions with flow rates approaching or above $1 \mathrm{~mL} \mathrm{~min}^{-1}$ and hence the formation of product at a rate $>1 \mathrm{~g} \mathrm{~h}^{-1}$. Indeed the larger Ammonite 15 cell allowed the use of flow rates up to $16 \mathrm{~mL} \mathrm{~min}^{-1}$ and product formation rates $>20 \mathrm{~g} \mathrm{~h}^{-1}$ [5]. Such cells can also be operated with cheap pumps and constant current sources. It should be recognised that these cells are designed for laboratory synthesis and not as a model for substantial scale up. In the laboratory, the emphasis is on achieving high selectivity and conversion while current efficiency and energy consumption are less important. Chapman et al. [6] have also described an extended channel cell based on a stack of 5 cells each containing a 'snake like' channel , 4 $\mathrm{mm}$ wide and $0.2 \mathrm{~m}$ in length giving a total channel length of $1 \mathrm{~m}$. Although not an extended channel cell, Gütz et al. [7] have reported a divided flow cell design with similar goals; the cell employs a traditional parallel plate cell design but with a comparatively low linear flow rate to achieve high conversion. However, the width of the channel allows the use of a volumetric flow rate consistent with the formation of grams of a pharmaceutical intermediate. All these designs emphasise the need for electrolysis cells that are convenient for selective laboratory synthesis on a multi-gram scale. 
With the flow rates conveniently used with these extended channel microfluidic electrolysis cells, the residence time of the reactant in the cell (volume of cell channel/flow rate) is usually well below 1 minute. This is quite unlike beaker cells and multicycle cells when the residence time in the system is effectively many hours. The low residence time greatly diminishes the role of competing homogenous chemistry.

Good performance for organic electrosyntheses in these cells is, however, dependent on operating the cells within a narrow range of operating parameters. In particular, the cell current must be appropriate for the flow rate and this is discussed in this review. In addition, the extended channel microflow cells described to date are undivided and, in such cells, the counter electrode chemistry must be taken into consideration. In terms of electrons, the same amount of chemistry occurs at both counter and working electrode and clean synthesis in high yield is dependent on a counter electrode reaction that neither contaminates the product stream or consumes reactant or product. Even so, a wide range of chemistry can be carried out in these microflow cells with extended channel length and this is also illustrated herein.

\section{Selection of Reaction Conditions and Control Parameters}

\section{(a) Cell Current and Solution Flow Rate}

Full conversion of reactant to product both maximises the product yield and simplifies the isolation of pure product. Full conversion in a single pass in an electrolysis is dependent on passing a large enough charge through the cell to satisfy mass balance in the synthesis reaction (considered as an oxidation, Figure 3) within the time the reactant is in the microflow cell.

$$
\mathrm{R}-\mathrm{ne}^{-} \longrightarrow \mathrm{O}
$$

Figure 3. Oxidation of $\mathrm{R}$ to $\mathrm{O}$ involving removal of $\mathrm{n}$ electrons

The cell current is calculated using Faraday's law; assuming no competing electrode reactions, the charge for full conversion is $m n F$ where $m$ is the number of moles of reactant, $n$ the number of electrons per reactant molecule involved in the synthesis reaction and $F\left(\mathrm{C}\right.$ mole $\left.{ }^{-1}\right)$ the Faraday constant (the charge on a mole of electrons). Therefore, the minimum cell current, $I_{\text {cell.minimum }}$ (amps), for full conversion is given by

$$
I_{\text {cell,minimum }}=m n F / t
$$

where $t(\mathrm{~s})$ is the time for the total reactant solution containing $m$ moles of reactant to pass through the cell. If the cell current is below this value, full conversion cannot be achieved because not enough charge is passed to complete the reaction during the residence time of the reactant in the cell. If the cell current is higher than $I_{\text {cell.minimum, }}$, then a competing reaction must 
be occurring at the working electrode because there is insufficient reactant in solution (the product is being degraded by over oxidation or solvent/electrolyte is being oxidised). It is clear from eq. 1 that the required cell current will increase proportional to the concentration of reactant in the inlet solution (more charge required for full conversion) and the flow rate of the reactant solution through the microflow channel (the residence time of reactant in the cell is decreased, with a corresponding reduction of the total time $(t)$ to pass the reactant solution).

It is important to recognise that it is inherent in any flow electrolysis cell designed to give full conversion in a single pass that the current distribution over the working electrode surface is very non-uniform. The current density must be high close to the inlet where the reactant concentration is high and drop towards zero at the outlet when the reactant has been converted to product. The simplest model for the cells shows that the local current and the reactant concentration both decay exponentially with distance along the electrode [4b].

In addition, clean synthesis requires that the desired electrode reaction is the predominant, and preferably, the only chemical change at the electrode at all points along the microflow electrolysis channel. This is only possible if the desired chemical change is fast enough. The maximum rate at which chemical change occurs at an electrode surface is always limited by the rate at which the reactant reaches the surface and the fastest chemical change occurs when the synthesis reaction is mass transfer limited at all points on the working electrode. During electrolyses in an extended channel microflow cell, the overall rate of chemical change is proportional to the cell current and the cell current, $I_{c e l l, m t}$ (amps), is the sum of the currents along the channel. If the reaction is mass transfer controlled, the cell current is given by

$$
I_{c e l l, m t}=\int_{0}^{L} I_{x, m t} d x=n F w \int_{0}^{L} k_{m . x} c_{x} d x
$$

where $x(\mathrm{~cm})$ is the distance along the channel, $I_{x, m t}$ (amps) the mass transport limited current at the distance $x$ along the channel and $L$ the total length of the channel, $w(\mathrm{~cm})$ is the width of the microflow channel, $k_{m, x}\left(\mathrm{~cm} \mathrm{~s}^{-1}\right)$ the mass transfer coefficient at the distance $\mathrm{x}$ along the channel and $c_{x}\left(\mathrm{~mol} \mathrm{~cm}^{-3}\right)$ the concentration of reactant at this distance. The mass transfer coefficient characterises the mass transfer regime in the microflow channel and in the simplest situation is only determined by the dimensions of the channel and the flow rate of the reactant solution through the cell. In general, however, it can be influenced by corners in the flow path, temperature gradients along the channel and by gas evolution at either electrode (gas bubbles act as turbulence promoters while the volume of gas increases the linear flow rate of the reactant solution through the cell) [8]. Then, the mass transfer coefficient becomes a function of 
distance along the channel. Although the mass transfer coefficient (and hence the cell current) depends on the flow rate, the relationship is less than first order and therefore the highest conversions are obtained at low flow rates. Certainly, it is clear that efficient mass transport (high $k_{m}$ ) is advantageous in seeking a high conversion and product formation rate. Provided full conversion is maintained, a high flow rate is clearly advantageous in achieving a high rate of product formation.

To achieve full conversion using the cell current, $I_{\text {cell,minimum }}$, the synthetic reaction must be occurring without competing reactions and this is only possible if the mass transport controlled cell current is large enough that only the synthesis reaction is occurring at the working electrode, i.e. $I_{c e l l, m t}$ must be greater than $I_{\text {cell,minimum. }}$ Where the mass transport is not sufficient to maintain $I_{\text {cell.minimum }}\left(\right.$ i.e. $I_{\text {cell,mt }}<I_{\text {cell.minimum }}$ ) a competing electrode reaction must be occurring.

For a mass transfer controlled reaction, the actual fractional conversion, $X$, for any solution flow rate, $f\left(\mathrm{~cm}^{3} \mathrm{~s}^{-1}\right)$, can be estimated from eq. 3

$$
X=1-c_{\text {out }} / c_{\text {in }}=1-\exp ^{-k_{m} w L} / f
$$

where $w(\mathrm{~cm})$ is the width of the channel, $L(\mathrm{~cm})$ the length of the channel and $k_{m}\left(\mathrm{~cm} \mathrm{~s}^{-1}\right)$ the length averaged mass transfer coefficient $[4 a, b]$. If the reaction is not mass transfer controlled, the fractional conversion will be less.

To summarise, full conversion of reactant to product is only possible if

- the cell current is high enough that the charge demanded by Faraday's law (mass balance) is passed while the reactant remains in the microflow cell, i.e.

$$
I_{\text {cell }} \geq I_{\text {cell,minimum }}
$$

- the synthesis reaction is fast, ideally mass transfer controlled and the mass transfer conditions are good enough that the mass transfer controlled cell current for the synthesis reaction exceeds this current, i.e.

$$
I_{\text {cell }} \leq I_{\text {cell,mt }}
$$

- the length of the microflow channel is sufficient at the flow rate used.

In ideal conditions where there is only the synthesis reaction occurring at the working electrode and full conversion can be achieved, the rate of product formation is given by

$$
\text { Rate of product formation }=m / t \quad \text { (eq. } 4 \text { ) }
$$

In most situations, the fractional conversion, $X$, is less than one and reactions of intermediates in the synthesis reaction lead to some byproduct so that the fractional selectivity, $\phi$, is also less than one, when the rate of product formation will be less and given by 


$$
\text { Rate of product formation }=\phi X m / t
$$

$\phi X$ is the chemical yield of product which can be used directly. The rate of formation of the product may be increased by increasing the reactant concentration in the feed or the flow rate of the reactant but either will require an increased cell current and maintaining the synthesis reaction as the sole/dominant reaction at the working electrode.

In most cases, with a new electrosynthesis, several of the quantities in the discussion (e.g. the mass transfer coefficient, the reaction selectivity and possible conversion) will not be known. The above discussion is therefore intended to provide an understanding of the concepts of extended channel length microfluidic cells essential to optimum use of the cells. In practice, the performance of the cells must be determined experimentally but it is strongly recommended that the initial experiments use a cell current slightly above the value of $I_{\text {cell,minimum }}$ calculated from eq. 1 and flow rate suitable for the cell and reaction.

\section{(b) Cell Chemistry}

In a constant current electrolysis, at both electrodes chemical change must occur at a sufficient rate to support the passage of the current through the cell. In each case, the reaction will be the oxidation/reduction that occurs most readily, i.e. at the anode, the oxidation that occurs at the least positive potential and at the cathode, the reduction that occurs as least negative potential. These will be the only reactions if the cell current is less than the mass transfer controlled current for these reactions. If not, a competing reaction must occur and if the synthesis is an oxidation, this will be the oxidation reaction that occurs at a potential closest to that for the synthesis reaction.

Clearly, good performance in the microfluidic flow electrolysis cell is dependent on a clean synthesis reaction at the working electrode. This requires that the electron transfer reaction at the working electrode produces a single reaction intermediate and that this intermediate decays in a dominant single pathway. There is an extensive literature on organic electrosynthesis and the voltammetry of organic molecules [9] although it can often be a poor guide to what can be achieved in microflow cells; too frequently, papers employ low concentrations of reactant, beaker cells with ill-defined geometry and mass transfer regime and electrolyses are terminated at low conversion. Even so, the literature and particularly data on the potentials for oxidation/reduction of each functional group is a helpful guide to those reactions that are likely to have a good selectivity in the extended channel microflow cells.

With electrolysis in beaker or macroflow cells, the residence time of reactant and product in the cell is usually hours and this gives rise to the possibility for degradation of 
performance due to slow homogeneous reactions, e.g. hydrolysis. In extended channel length microflow cells, the residence time in the cell is determined by the flow rate of reactant solution. It is generally less than 1 minute and can be as short as $\sim 10 \mathrm{~s}$. This significantly decreases the opportunity for unwanted competing chemistry.

In addition, in all electrolysis cells, in terms of electrons, equal quantities of chemical change must occur at both working and counter electrodes. In many electrolysis cells a separator (e.g. an ion permeable membrane, a porous polymer sheet, a glass sinter) is used to keep apart the anode and cathode chemistries. Including a separator in a microfluidic flow cell significantly increases the complexity of the design and fabrication procedure. Hence, most such cells to the present are undivided. But in undivided cells with narrow interelectrode gaps, it is essential to consider the combination of anode and cathode chemistries on the cell performance. In general, several undesirable reactions are possible. For example, if the desired synthesis reaction at the working electrode is an oxidation, the counter electrode reaction could be (a) reduction of the reactant or synthesis product decreasing yield and introducing byproducts (b) in aprotic organic solvents reduction of the solvent/electrolyte commonly leads to a complex mixture of products that become impurities in the synthesis product leaving the cell.

Hence, it is necessary to consider the overall chemical change in the undivided cell. A compelling scenario would be a cell where there are two reactants and the same product is formed at both anode and cathode in high yield; such systems are unlikely. Another attractive approach is the 'paired synthesis' [10] where two reactants are converted to two products in separate syntheses at anode and cathode. In restricted circumstances, this can be achieved and there is even one example that has been carried out on an industrial scale [11]. In protonic media the most general approach is to use the counter electrode to maintain a constant $\mathrm{pH}$ along the channel. In the majority of anodic syntheses $1 \mathrm{H}^{+} / \mathrm{e}^{-}$is formed while at the cathode $1 \mathrm{H}^{+} / \mathrm{e}^{-}$ is consumed or an equivalent amount of base is formed. Hence generation of base at the cathode can be used to balance the $\mathrm{pH}$ along the channel and this is the approach used in the methoxylation of $N$-formylpyrrolidine (Scheme 1) [4a-c,5].

At first sight, using a separator between the two electrodes appears to simplify the chemistry. This is not entirely the case. Blocking the cathode chemistry from the anolyte with a separator is likely to make the anolyte become acidic as it passes through the microflow cell, not ideal for acid sensitive reactants/products. With a $0.5 \mathrm{M}$ solution of reactant for a synthesis involving a $2 \mathrm{e}^{-}$oxidation, the exit solution must be expected to be $1 \mathrm{M}$ in $\mathrm{H}^{+}$. Using an undivided cell can therefore be an advantage. But particularly in undivided cells, it is critical to consider the total chemical change (anode + cathode chemistries) occurring in the cell. 


\section{(c) Other Factors}

With electrolyses in the microfluidic electrolysis cells with extended channel lengths using aqueous or alcohol based electrolytes or media containing an acid, hydrogen evolution is a convenient counter electrode reaction; the proton consumed or base formed also ensures a constant ' $\mathrm{pH}$ ' for the anode chemistry along the channel. Originally, there was a concern that the gas formed would block the microflow channel. Experience shows that this is not the case and, indeed, the performance found when $\mathrm{H}_{2}$ is evolved is superior to that predicted by the simple theory [4a-c]. This can be understood in terms of an enhanced mass transfer coefficient resulting from turbulence around small gas bubbles and the gas volume formed increasing the linear flow rate of solution through the cell. The enhanced mass transfer regime will lead to an improved selectivity through a higher mass transfer controlled cell current for the synthesis reaction, $I_{c e l l, m t}$ (see eq. 2) as well as an improved conversion (see eq. 3).

The rate of product formation can be increased by increasing either the concentration of reactant or the flow rate of the solution through the cell. Both strategies necessitate an increase in cell current in order to achieve a high conversion. One consequence is an increase in the volume of $\mathrm{H}_{2}$ gas formed and at higher cell currents this can be significant. For example, a cell current of 1 A will lead to the evolution of $\sim 7 \mathrm{~cm}^{3} \mathrm{~min}^{-1}$ of gas, comparable to the flow rate of reactant solution and therefore leading to a significant increase of the flow rate. Cell currents in the Ammonite 15 can be higher than $10 \mathrm{~A}$. A second consequence is Joule heating of reactant solution as it passes through the cell. The increase in temperature depends on the cell current and the residence time of the reactant solution in the cell. When the inlet solution is at room temperature, heating is generally not significant for cell currents $<1$ A. For larger cell currents there can be a temperature increase large enough to increase the mass transfer coefficient (advantageous) but also to cause concern about a degradation of reaction selectivity. Temperature rise becomes more of an issue for electrolyses with low/no electrolyte in organic solvents or where a cooled inlet solution is desirable. Then cooling of the cell is essential.

Electrolyte removal during isolation of pure product is often considered an unwanted complication. Therefore, operating with no/low electrolyte in the reactant solution is always of interest. Electrolyte is certainly unnecessary when the reactant is charged, and, in any case, even with neutral reactants, ions are rapidly formed close to the inlet where the current density is high. Even so, when the electrolyte is easily removed, we commonly employ $50 \mathrm{mM}$ electrolytes to minimise the applied cell voltage and hence the temperature rise but we routinely test reactions with only $5 \mathrm{mM}$ electrolyte without observing a significant loss of performance [4a-c]. 


\section{Illustrative Electrosyntheses}

\section{(a) Anodic Methoxylation}

The methoxylation of $N$-formylpyrrolidine in methanol/Et $\mathrm{NBF}_{4}$ to give 2-methoxy- $N$ formylpyrrolidine is a reaction well suited to the undivided microfluidic electrolysis cell (Scheme 1) [12,13]. It is an example of a synthesis where the counter electrode reaction is hydrogen evolution and the reaction serves to avoid the build up of acid along the channel.

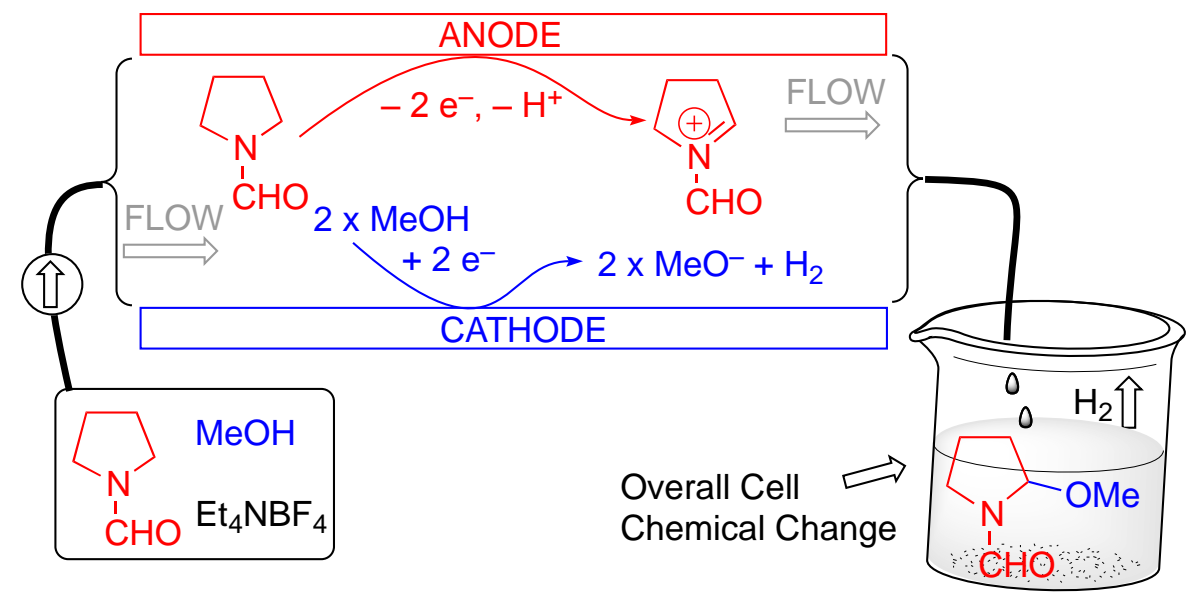

Scheme 1. Anodic methoxylation of $N$-formylpyrrolidine

Table 1 compares the performance for the methoxylation of $N$-formylpyrrolidine in the three extended channel, microflow cells with carbon filled PVDF anode and stainless steel cathode [4a-c,5]. In all three cells, it is a selective reaction and high fractional conversions to the methoxylated product can be achieved. Indeed at low flow rates, the cells may be used interchangeably. The use of the larger cell with longer channel length does, however, allow the employment of higher flow rates with consequent increase in the rate of product formation. Significantly, added electrolyte is easily recovered by precipitation from the crude reaction mixture, and can be reused many times. 


\begin{tabular}{|c|c|c|c|c|c|}
\hline cell & $\begin{array}{l}\text { flow rate/ } \\
\mathrm{mL} \min ^{-1}\end{array}$ & $\mathrm{I}_{\text {cell }} / \mathrm{A}$ & $\begin{array}{l}\text { fractional } \\
\text { conversion }\end{array}$ & $\begin{array}{l}\text { fractional } \\
\text { selectivity }\end{array}$ & $\begin{array}{l}\text { product } \\
\text { formation } \\
\text { rate } / \mathrm{g} \mathrm{h}^{-1}\end{array}$ \\
\hline \multirow{3}{*}{$\begin{array}{l}\text { Syrris cell } \\
0.2 \times 1.5 \times 700 \mathrm{~mm}\end{array}$} & 0.1 & 0.04 & 1.00 & 0.95 & 0.07 \\
\hline & 0.5 & 0.25 & 1.00 & 0.90 & 0.35 \\
\hline & 3.0 & 0.80 & 0.80 & 0.90 & 1.7 \\
\hline \multirow{3}{*}{$\begin{array}{l}\text { Ammonite } 8 \\
0.5 \times 2 \times 1000 \mathrm{~mm}\end{array}$} & 0.5 & 0.20 & 1.00 & 0.95 & 0.37 \\
\hline & 1.0 & 0.40 & 0.86 & 0.95 & 0.64 \\
\hline & 3.0 & 1.50 & 0.88 & 0.91 & 1.9 \\
\hline \multirow{3}{*}{$\begin{array}{l}\text { Ammonite } 15 \\
0.5 \text { x } 5 \text { x } 2000 \mathrm{~mm}\end{array}$} & 2.0 & 1.00 & 1.00 & 0.73 & 1.1 \\
\hline & 5.0 & 2.00 & 0.84 & 1.00 & 3.3 \\
\hline & 16.0 & $12.00^{a}$ & 0.88 & 0.95 & 20.7 \\
\hline
\end{tabular}

Table 1. Performance of the extended channel length electrolysis cells for the methoxylation of $N$-formylpyrrolidine (Scheme 1). $\mathrm{MeOH} / \mathrm{Et}_{4} \mathrm{NBF}_{4}(0.05 \mathrm{M})$. Carbon-filled PVDF anode / stainless steel cathode. Reactant concentration 0.1 M. Channel dimensions; interelectrode gap $\mathrm{x}$ channel width $\mathrm{x}$ channel length. ${ }^{a}$ Reaction performed on a $0.2 \mathrm{M}$ solution of $N$-formylpyrroldine

Kabeshov et al. [14] have reported a number of $\alpha$-methoxylations of $N$-protected cyclic amines in an undivided, extended channel microflow cell, all giving yields above $90 \%$. One was used in a two-step synthesis of the alkaloid, nazlinine, which displays serotonergic properties.

The benzylic methoxylation of activated toluene derivatives can be very efficient and scalable electrochemical reactions $[11,15]$ and the reaction has also been studied in microflow cells $[2 \mathrm{c}, 4 \mathrm{c}, 4 \mathrm{e}, 16]$ An example carried out in the microflow cell is the oxidation of 4-tbutyltoluene in methanol (Scheme 2). In a cell with a steel cathode so that the counter electrode reaction was hydrogen evolution, and after aqueous acid treatment of the cell outlet solution, the fractional conversion to 4- $t$-butylbenzaldehyde was $>0.95$, with an unoptimized yield of 4$t$-butylbenzaldeyhde of $58 \%$ on a gram scale (current efficiency $=37 \%$ based upon isolated yield) [17]. This reaction was also carried out as a paired synthesis. Using a cell with two carbon/PVDF electrodes, the feed solution contained equal concentrations of dimethyl phthalate (1) and 4-t-butyltoluene. The conversion to 4-t-butylbenzaldehyde at the anode was again high but the cathode reaction was less efficient; the fractional yield of phthalide (2) was $60 \%$ and the current efficiency was $54 \%$ [17]. 

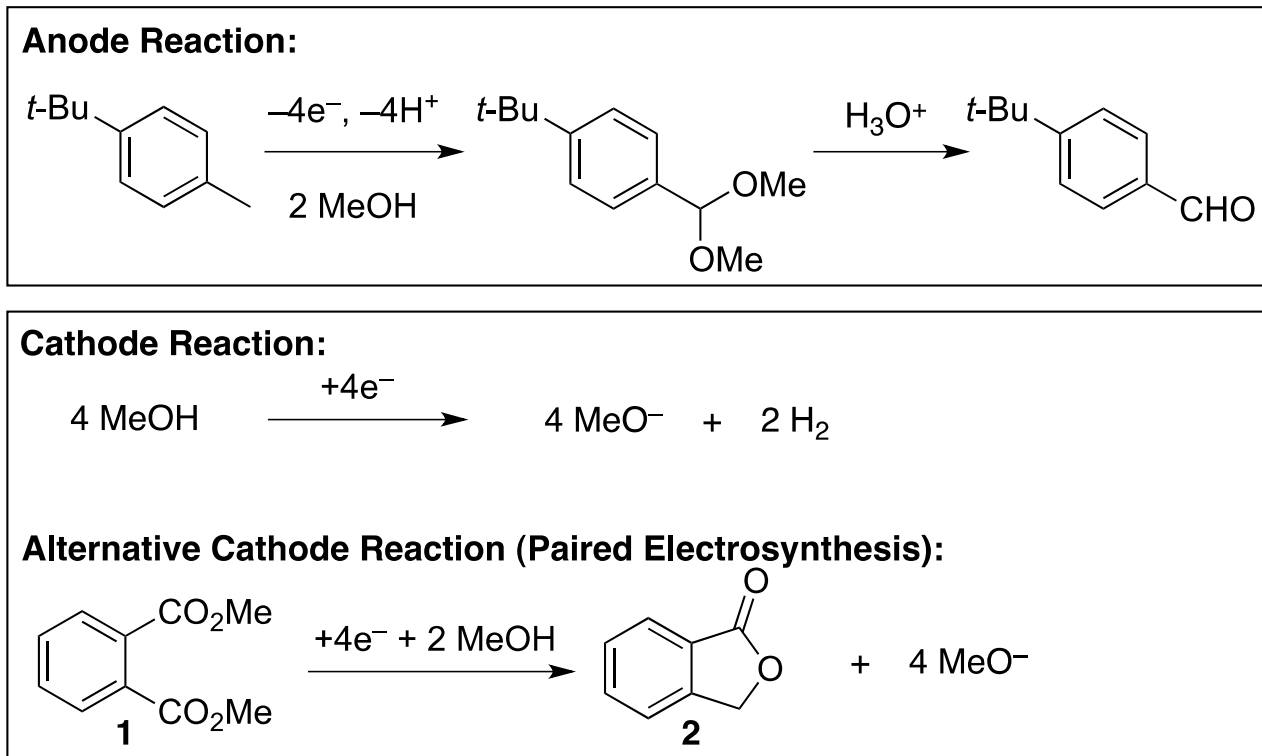

Scheme 2. Anodic methoxylation of 4-t-butyltoluene, and paired cathodic reduction of dimethyl phthalate (1)

(b) Formation of Quinone Ketals

Intramolecular alkoxylation is also possible to produce quinone bis- and monoketals [18], which are useful intermediates in synthesis including application in interesting photochemical transformations $[18,19]$. One example carried out in a flow cell with carbon filled PVDF anode and stainless steel cathode is shown in scheme 3 using a methanol/KOH electrolyte [17]. The conversion of hydroquinone diether 3 was $>90 \%$ and quinone bis- and monoketals 4 and 5 were formed in a ratio of 4:1, respectively. Subsequent acidic hydrolysis can be used to transform the bis-ketal $\mathbf{8}$ to monoketal $\mathbf{5}$.

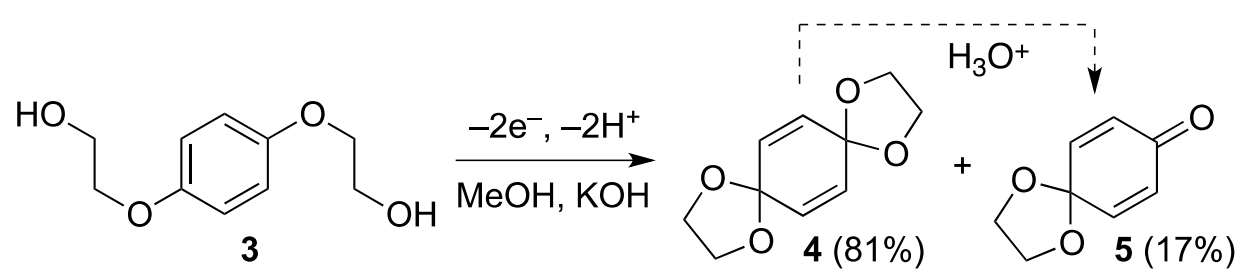

Scheme 3. Anodic oxidation of hydroquinone diether to quinone ketals

\section{(c) Fluorination}

A large number of selective monofluorination reactions using ionic liquid salts such as $\mathrm{Et}_{3}$ N.3HF in aprotic solvents as the electrolyte have been reported [20]. Table 2 reports some results for the fluorination of $\mathrm{PhSCH}_{2} \mathrm{COOEt}$ (6) in a microfluidic flow cell using $\mathrm{Et}_{3}$ N.3HF/DME as the electrolyte (Scheme 4) [17]. The results are very promising with yields of the monofluorinated product $7>70 \%$ with only a trace of difluorinated product 8 provided excess Et ${ }_{3}$ N.3HF was not present. When the concentration of fluorine source was doubled, substantially more difluorinated product was formed. Using the ionic liquid as the source of 
fluoride, the addition of a further electrolyte is unnecessary while the yield of monofluorinated product is slightly higher using a Pt anode compared to the $\mathrm{C}$ filled PVDF anode. Again, in this acidic medium the counter electrode reaction is $\mathrm{H}_{2}$ evolution preventing the electrolyte becoming more acidic though the cell.

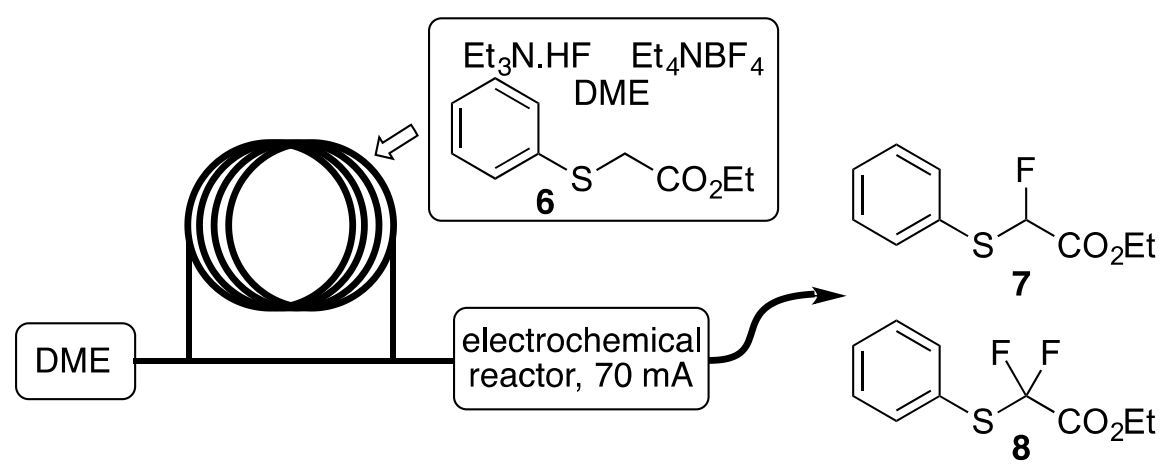

Scheme 4. Anodic fluorination of ethyl 2-(phenylthio)acetate (6) ${ }^{a}$

\begin{tabular}{|c|c|c|c|c|}
\hline anode & concentration & concentration & \multicolumn{2}{|c|}{ yield $^{b}$} \\
\cline { 3 - 5 } material & $\mathrm{Et}_{3} \mathrm{~N} .3 \mathrm{HF} / \mathrm{mM}$ & $\mathrm{Bu}_{4} \mathrm{NBF}_{4} / \mathrm{mM}$ & $\mathbf{7}$ & $\mathbf{8}$ \\
\hline \multirow{3}{*}{ C/PVDF } & \multirow{2}{*}{100} & 0 & $74 \%$ & $4 \%$ \\
\cline { 3 - 5 } & & 25 & $71 \%$ & $2 \%$ \\
\cline { 3 - 5 } & & 50 & $77 \%$ & $2 \%$ \\
\cline { 3 - 5 } & 200 & 100 & $70 \%$ & $3 \%$ \\
\cline { 3 - 5 } & 100 & 0 & $67 \%$ & $28 \%$ \\
\hline $\mathrm{Pt}$ & & 50 & $82 \%$ & $2 \%$ \\
\hline
\end{tabular}

Table 2. ${ }^{a}$ Fluorination of $6(100 \mathrm{mM})$ in a cell with $\mathrm{C}$ filled PDVF or Pt anode and stainless steel cathode. Electrolyte $\mathrm{Et}_{3} \mathrm{~N} .3 \mathrm{HF} / \mathrm{DME}+\mathrm{x} \mathrm{mM} \mathrm{Bu}_{4} \mathrm{NBF}_{4}$. Flow rate $0.1 \mathrm{~mL} \mathrm{~min}^{-1}$. Cell current $70 \mathrm{~mA} .{ }^{b}$ Yields determined by ${ }^{19} \mathrm{~F}$ NMR.

\section{(d) Kolbe Reaction}

The Kolbe reaction is never mass transport controlled. It occurs via a mechanism that involves adsorbed radical intermediates and oxygen evolution is always a likely competing reaction. Hence, full conversion is more difficult to achieve and the optimum cell current for the microfluidic flow cell must be sought experimentally. The literature [21] states that for the radical-radical coupling to form dimer, $\mathrm{Pt}$ is the preferred anode material. It also suggests that a high concentration of carboxylic acid and a high current density is advantageous and methanol containing partially $(10-25 \%)$ neutralised carboxylic acid is a suitable medium.

The formation of dimethyl adipate (10) from the half ester of succinic acid 9 was examined (Scheme 5). Again, the cathode reaction is hydrogen evolution with the methoxide formed converting further acid to carboxylate. Early experiments confirmed that little dimer was formed with low carboxylic acid concentrations or low cell currents. Indeed, the carboxylic acid concentration needed to be $>0.5 \mathrm{M}$ and the cell current needed to be very high, so that the charge input was at least 2.5 times that for full conversion, calculated using eq. 1 . 
In these conditions, yields of the dimer of 50-60\% could be obtained, with current efficiencies of $\sim 10 \%$ [17]. Higher yields could not be obtained presumably because the chemistry becomes less favourable as the carboxylate concentration drops along the microflow channel.

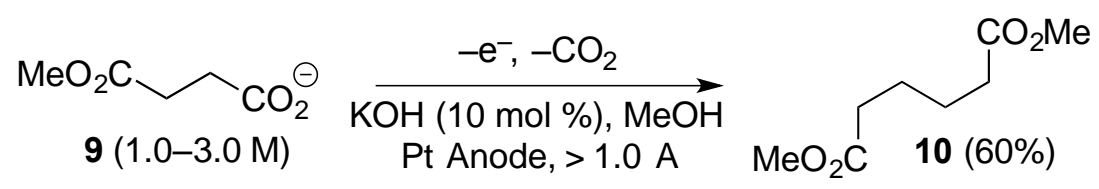

Scheme 5. Kolbe reaction to form dimethyl adipate

(e) Cerium (IV) Generation

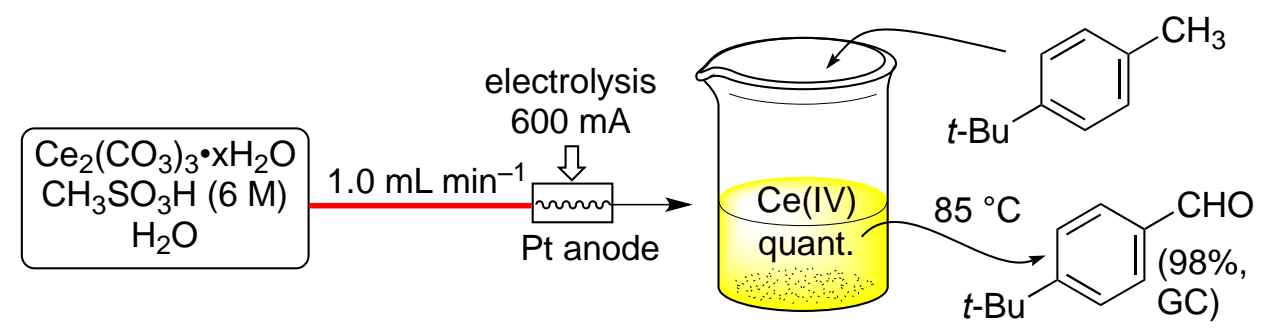

Scheme 6. Electrochemical generation of Ce(IV)

In order to test the viability of using the extended channel microflow electrolysis cells for the generation of inorganic redox reagents, the oxidation of $\mathrm{Ce}$ (III) to $\mathrm{Ce}$ (IV) in $1.5 \mathrm{M}$ methanesulfonic acid was investigated (Scheme 6) [22]. The yields of $\mathrm{Ce}(\mathrm{IV})$ were higher at Pt than $\mathrm{C}$ filled PVDF presumably because of faster electron transfer kinetics and less interference from $\mathrm{O}_{2}$ evolution. With a $\mathrm{Pt}$ anode, the current efficiency was $\sim 66 \%$ and conversion was $>90 \%$ as determined by $\mathrm{Fe}(\mathrm{II})$ titration of the produced $\mathrm{Ce}(\mathrm{IV})$ solution [17]. At first inspection, this is a surprising result since in an undivided beaker cell with equal anode and cathode areas, one might expect partial conversion due the reverse reaction reducing Ce(IV) to $\mathrm{Ce}(\mathrm{III})$ at the counter electrode. This reverse reaction is not significant in the extended channel microflow cell, where uneven distribution of reaction along the channel results in the majority of the $\mathrm{Ce}(\mathrm{IV})$ being formed early in the channel when little $\mathrm{Ce}(\mathrm{IV})$ is present. The kinetics of $\mathrm{Ce}(\mathrm{IV})$ reduction are slow at the stainless steel cathode, where formation of $\mathrm{H}_{2}$ gas from reduction of $\mathrm{MeSO}_{3} \mathrm{H} / \mathrm{H}_{2} \mathrm{O}$ is the dominating counter electrode process.

The high conversion to $\mathrm{Ce}(\mathrm{IV})$ was confirmed by reaction of the electrochemically produced solution with excess $t$-butyltoluene at a temperature of $80{ }^{\circ} \mathrm{C}$ [18], affording 4-tbutylbenzaldehyde in excellent isolated yield ( $96 \%$ based on $\mathrm{Ce}(\mathrm{III})$ in the cell inlet solution). 


\section{(f) TEMPO Mediated Alcohol Oxidation}

As a general process, the conversion of alcohols to aldehydes or ketones only gives poor yields when attempted as a direct electrode reaction. This has led to studies focused on the development of homogeneous catalytic mediators for these important functional group interconversions. TEMPO (11) [23] has become a preferred mediator where the anode reaction is used to regenerate the active species, the oxoammonium ion 12 (Scheme 7), avoiding the use of excess co-oxidant as employed in the chemical process.

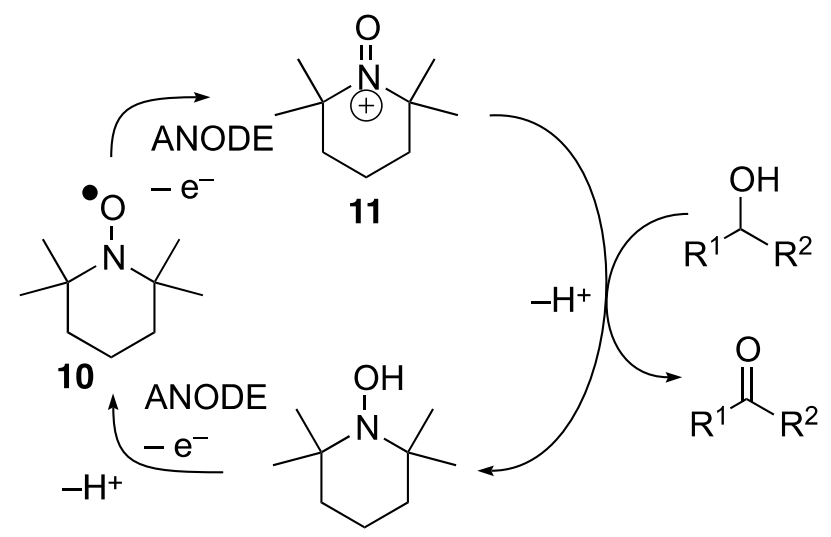

Scheme 7. Electrocatalytic alcohol oxidation

Ideally, for electrosynthesis in an extended channel length microflow cell, the conversion should be mass transfer controlled with respect to the alcohol and only a low concentration of TEMPO would be used. This requires that all chemical steps in the reaction sequence converting alcohol to aldehyde are rapid. Unfortunately, while the electron transfer steps are fast, the chemical steps in the sequence are comparatively slow. A medium was, however, developed where good conversions and yields were obtained employing 30 mol \% TEMPO (Scheme 8) [24]. This medium was a $t$-butanol/water mixture containing a carbonate/bicarbonate buffer, $\mathrm{pH}$ 11.5. The generality of the procedure was demonstrated with 15 different substrates [24a]. The fractional selectivities were generally $>0.95$ with the fractional conversions in the range $0.50-0.95$ depending on the kinetics of the oxoammonium ion/alcohol reaction. Again, the anode was carbon filled PVDF and the counter electrode reaction in the undivided cell is hydrogen evolution with the hydroxide formed maintaining a constant $\mathrm{pH}$ along the flow channel. 


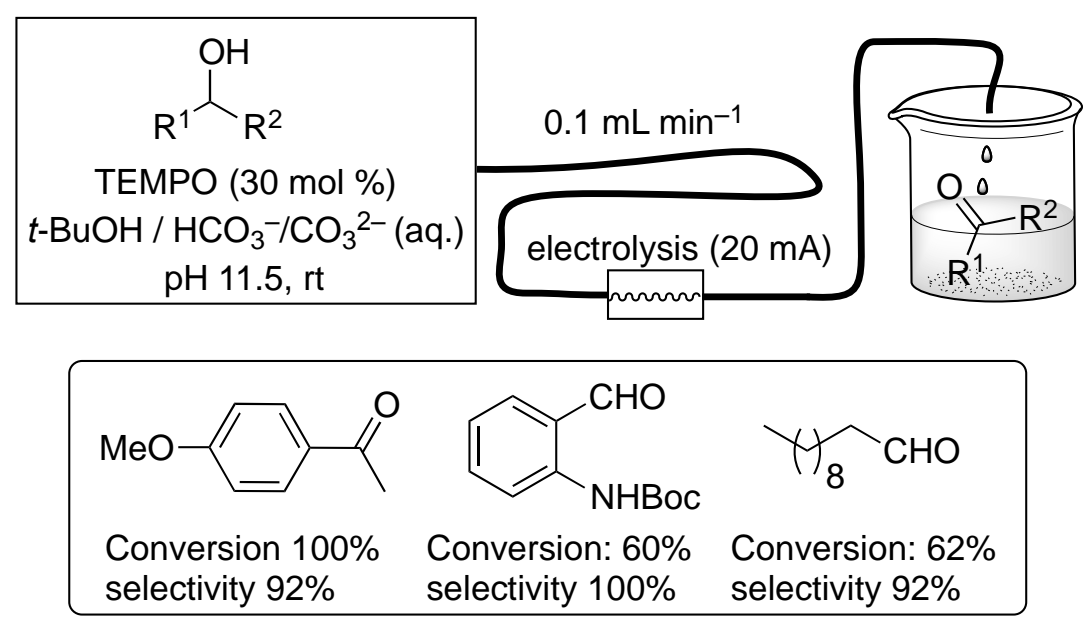

Scheme 8. Oxoammonium ion mediated electrocatalytic alcohol oxidation in flow

(g) $\mathrm{N}$-Heterocyclic Carbene Mediated Conversion of Aldehydes to Esters and Amides

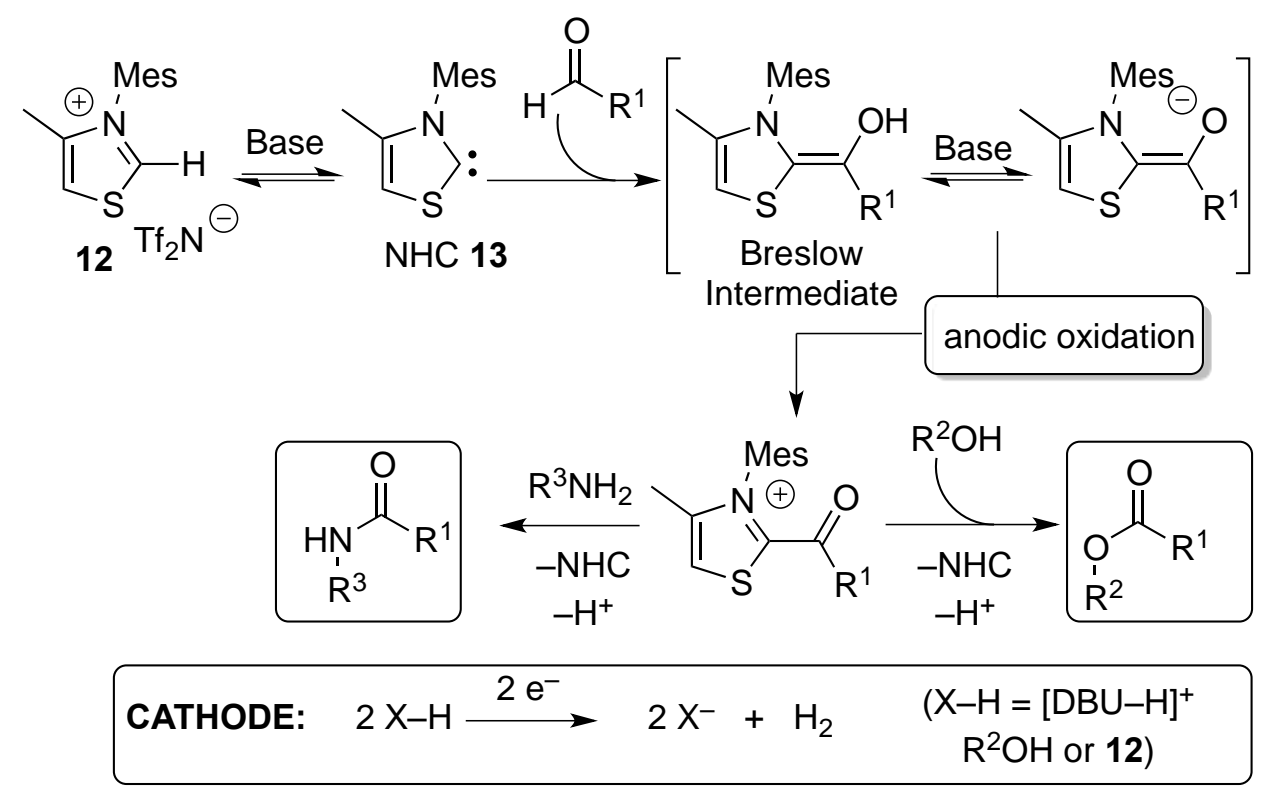

Scheme 9. NHC-mediated oxidative esterification and amidation reactions

The oxidation of Breslow intermediates formed in situ by the reaction of a $\mathrm{N}$ heterocyclic carbene (e.g. 13) with an aldehyde is a fruitful route for synthesis (scheme 9) [25], and it has recently been shown that the oxidation step can carried out at the C filled PVDF anode of an extended channel microflow electrolysis cell leading to the convenient conversion of aldehydes to esters $\mathbf{1 3}$ or amides $\mathbf{1 4}$ (schemes 10 and 11) [26]. 


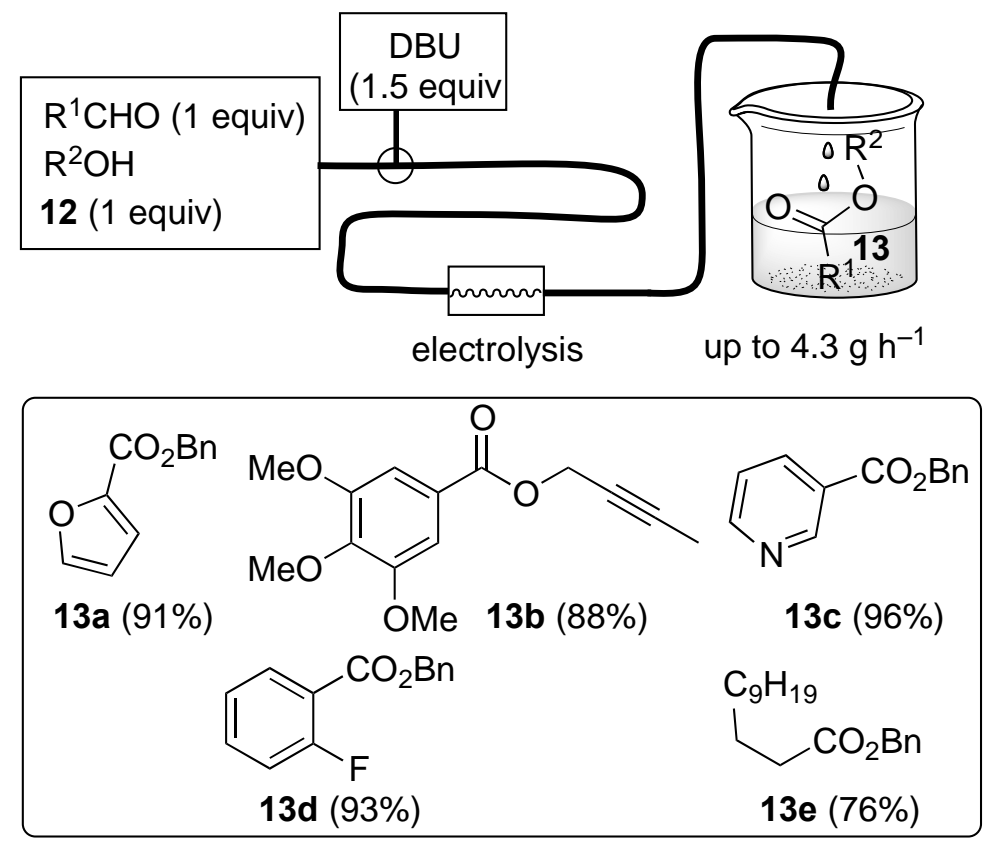

Scheme 10. Flow electrochemical NHC-mediated oxidative esterification

Both reactions were illustrated with a number of aldehydes and alcohols/amines and fractional yields were in the range $0.7-1.0$; in the case of the synthesis of amides it was necessary to heat the outlet solution from the cell to drive the reaction with amine to completion. Furthermore, the ability to control the mixing regimen so that the Breslow intermediate could form prior to mixing with the amine and subsequent electrolysis proved advantageous in avoiding imine formation, which otherwise inhibited the process. Electrolyses did not necessitate the addition of any added electrolyte and the reactions delivered productivity rates of several $\mathrm{g} \mathrm{h}^{-1}$ to produce up to $\sim 20 \mathrm{~g}$ of products.
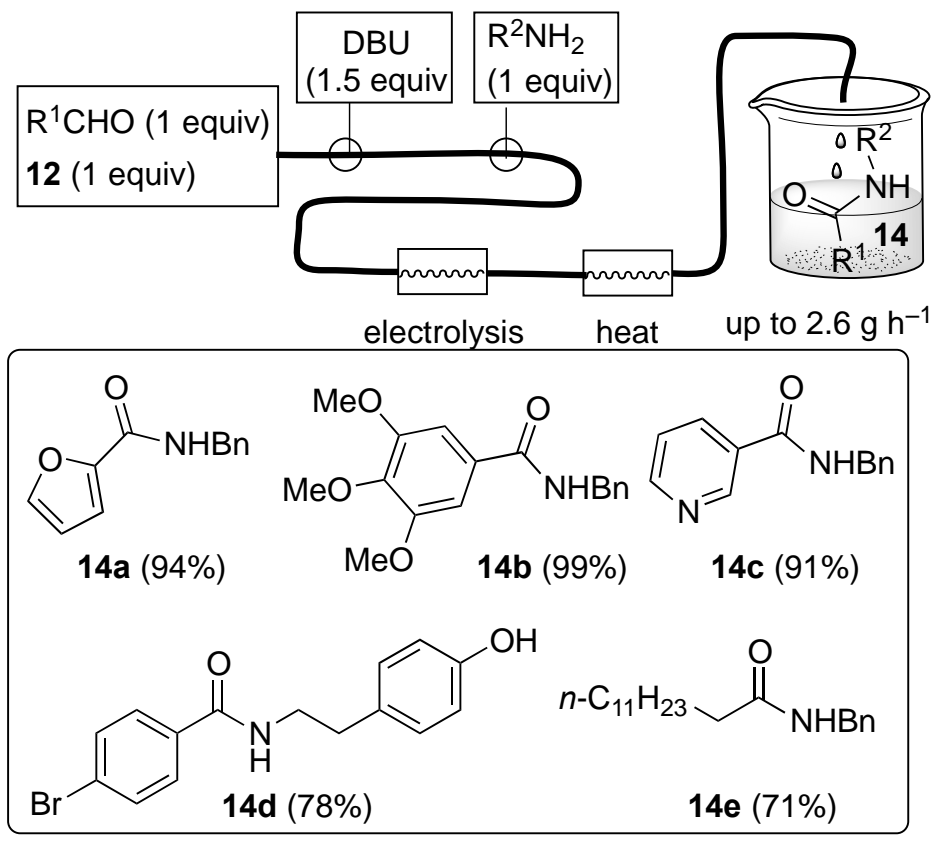

Scheme 11. Flow electrochemical NHC-mediated oxidative amidation 


\section{Conclusions}

It has been demonstrated that it is possible to achieve both high conversion and high selectivity for a variety of organic syntheses in the extended channel length microflow cells. The excellent performance is, however, dependent on the use of an appropriate cell current for the concentration of reactant and the flow rate through the microflow cell as well as the employment of compatible counter electrode chemistry. In view of the significant number of reported organic electrosyntheses in batch reactors, combined with current interest in continuous processing, flow electrosynthesis is likely to receive significant interest from industrial and academic communities in the coming years, enabled by commercially available extended channel length microflow cells.

\section{Acknowledgement}

The authors acknowledge the EPSRC for financial support to develop the extended channel length microflow electrolysis cells, and the syntheses described in this paper (EP/L003325/1: Factory in a Fumehood: Reagentless Flow Reactors as Enabling Techniques for Manufacture).

\section{References}

1. (a) Watts, P.; Haswell, S. J. Chem. Soc. Rev. 2005, 34, 235-246. (b) Mason, B. P.; Price, K. E.; Steinbacher, J. L.; Bogdan, A. R.; McQuade, D. T. Chem. Rev. 2007, 107, 23002318. (c) Fukuyama, T.; Rahman, T.; Sato M.; Ryu, I. Synlett. 2008, 151-163. (d) Yoshida, J. Flash Chemistry: Fast Organic Synthesis in Microsystems, Wiley-VCH: Weinheim, 2008. (e) Chemical Reactions and Processes under Flow Conditions, Luis S. V.; GarciaVerdugo, E., Eds. Royal Society of Chemistry, Cambridge, UK, 2009. (f) Microreactors in Organic Synthesis and Catalysis, $2^{\text {nd }}$ ed., Wirth, T., Ed. Wiley-VCH: Weinheim, 2013. (g) Microreactors in Preparative Chemistry, Reschetilowski, W., Ed. Wiley-VCH: Weinheim, 2013. (h) Pastre, J. C.; Browne, D. L.; Ley, S. V., Chem. Soc. Rev. 2013, 42, 8849-8869. (i) Porta, R.; Benaglia, M.; Puglisi, A., Org. Process Res. Dev. 2016, 20, 2 25. (j) Gemoets, H. P. L.; Su,Y.; Shang, M.; Hessel,V.; Luque, R.; Noël, T. Chem. Soc. Rev. 2016, 45, 83-117.

2. (a) Bouzek, K.; Jiřičný, V.; Kodým, R.; Křǐštál, J.; Bystroň, T. Electrochim. Acta. 2010, 55, 8172-8181. (b) Ziogas, A.; Kolb, G.; O’Connell, M.; Attour, A.; Lapicque, F.; Matlosz M.; Rode, S. J. Appl. Electrochem. 2009, 39, 2297-2313. (c) Attour, A.; Dirrenberger, P.; 
Rode, S.; Ziogas, A.; Matlosz M.; Lapique, F. Chem. Eng. Sci. 2011, 66, 480-489. (d) Watts, K.; Baker A.; Wirth, T. J. Flow Chem., 2014, 4, 2-11.

3. (a) Suga, S.; Okajima, M.; Fujiwara, K.; Yoshida, J. J. Am. Chem. Soc. 2001, 123, 79417942. (b) Yoshida. J. Chem. Commun. 2005, 4509-4516. (c) Horii, D.; Atobe, M.; Fuchigami T.; Marken, F. J. Electrochem. Soc. 2006, 156, D143-D147. (d) Horcajada, R; Okajima, M.; Suga, S.; Yoshida, J. Chem. Commun. 2005, 1303-1305. (e) Suga, S.; Okajima, M.; Fujiwara, K.: Yoshida, J. QSAR Comb. Sci. 2005, 24, 728-741. (f) Horii, D.; Amemiya, F.; Fuchigami, T.; Atobe, M. Chem. Eur. J. 2008, 14, 10382-10387. (g) Kashiwagi, T.; Amemiya, F.; Fuchigami, T.; Atobe, M. Chem. Commun. 2012, 48, 28062808. (h) Watts, K.; Gattrell, W.; Wirth, T.; Beilstein J. Org. Chem. 2011, 7, 1108-1114. (i) Arai, K.; Watts, K.; Wirth, T. ChemistryOpen, 2014, 3, 23-28. (j) Gütz, C.; Bänziger, M.; Bucher, C.; Galvão, T. R.; Waldvogel, S. R., Development and Scale-Up of the Electrochemical Dehalogenation for the Synthesis of a Key Intermediate for NS5A Inhibitors. Org Process Res Dev 2015, 19, 1428-1433.

4. (a) Kuleshova, J.; Hill-Cousins, J. T.; Birkin, P. R.; Brown, R. C. D.; Pletcher, D.; Underwood, T. J. Electrochim. Acta. 2012, 69, 197-202. (b) Green, R. A.; Brown, R. C. D.; Pletcher, D. J. Flow Chem. 2015, 5, 31-36. An earlier design was also reported, which was based on a tortuous extended length channel created by a polymer spacer between two flat electrode plates: (c) Kuleshova, J.; Hill-Cousins, J. T.; Birkin, P. R.; Brown, R. C. D.; Pletcher, D.; Underwood, T. J. Electrochim. Acta 2011, 56, 4322-4326. The Syrris electrolysis cell has also been applied to preparative electrosynthesis of drug metabolites: (d) Stalder, R.; Roth, G. P. ACS Med. Chem. Lett. 2013, 4, 1119-1123. (e) Roth, G.P.; Stalder, R.; Long, T.R.; Sauer, D. R.; Djuric, S. W. J. Flow.Chem. 2013, 3, 34-40.

5. Green, R. A.; Brown, R. C. D.; Pletcher, D. Org. Process Res. Dev. 2015, 19, 1424-1427.

6. Chapman, M. R.; Shafi, Y. M.; Kapur, N.; Nguyen, B. N.; Willans, C. E. Chem Commun. 2015, 51, 1282-1284.

7. C. Gütz, M. Bänziger, C. Bucher, T.R Galvão and S.R. Waldvogel, Org. Process Res. Dev. 2015, 19, 1428-1433.

8. Mallia, C. J.; Baxendale, I. R. Org. Process Res. Dev. 2016, 20, 327-360.

9. Organic Electrosynthesis, $4^{\text {th }}$ ed. Lund, H.; Hammerich, O. Eds. Marcel Dekker: New York, 2001.

10. Paddon, C. A.; Atobe, M.; Fuchigami, T.; He, P.; Watts, P.; Haswell, S. J.; Pritchard, G. T.; Bull S. D.; Marken, F. J. Appl. Electrochem. 2006, 36, 617-634. 
11. Steckhan, E.; Arns, T.; Heineman, W. R.; Hilt, G.; Hoormann, D.; Jörissen, J.; Kröner, L.; Lewall, B.; Pütter. H. Chemosphere 2001, 43, 63-73.

12. For selected examples of anodic methoxylation $\alpha$ to nitrogen see: (a) Shono, T.; Hamaguchi, H.; Matsumura, Y. J. Am. Chem. Soc., 1975, 97, 4264-4268. (b) Nyberg, K.; Servin, R.; Acta Chem. Scand. B, 1976, 10, 640-642. For selected reviews: (c) Moeller, K. D.; Tetrahedron 2000, 56, 9527-9554. (d) Steckhan, E. Anodic oxidation of nitrogencontaining compounds. In Organic Electrochemistry, $4^{\text {th }}$ ed.; Lund, H.; Hammerich, O., Eds. Marcel Dekker: New York, 2001; pp 545-588.

13. For some examples of anodic methoxylation $\alpha$ to nitrogen in flow reactors and cation trapping, see refs. [3a] and [3b].

14. Kabeshov, M. A.; Musio, B.; Murray, P. R. D.; Browne, D. L.; Ley, S. V. Org. Lett. 2014, $16,4618-4621$.

15. Pütter, H. Industrial Electroorganic Chemistry. In Organic Electrochemistry, $4^{\text {th }}$ ed.; Lund, H.; Hammerich, O., Eds. Marcel Dekker: New York, 2001; pp 1259-1307.

16. Attour, A.; Rode, S.; Ziogas, A.; Matlosz, M.; Lapicque, F. J. Appl. Electrochem. 2008, $38,339-347$.

17. See Supporting Information for experimental details

18. For examples in a batch electrochemical cell(a) Pirrung, M. C.; Nunn, D. S, Tetrahedron, 1996, 52, 5707-5738. (b) Pirrung, M. C.; Nunn. D. S., Tetrahedron Lett, 1988, 29, 163 166

19. Swenton, J. S. Chemistry of Quinone bis- and monoketals. In The Chemistry of Quinonoid Compounds, Patai, S.; Rappoport, Z. Eds.; John Wiley \& Sons: Chichester, 1988 Vol II, Chapter 15.

20. (a) Fuchigami, T. Electrochemical partial fluorination. In Organic Electrochemistry, $4^{\text {th }}$ ed.; Lund, H.; Hammerich, O., Eds. Marcel Dekker: New York, 2001; pp 1035-1050. (b) Fuchigami, T.; Inagi, S., Chem. Commun. 2011, 47, 10211-10223. (c) Noel, M.; Suryanarayanan, V.; Chellammal, S. J. Fluor. Chem. 1997, 83, 31-40. (d) Fuchigami, T. J. Fluor. Chem., 2007, 128, 311-316.

21. (a) Torii, S.; Tanaka, H. Carboxylic acids. In Organic Electrochemistry, $4^{\text {th }}$ ed.; Lund, H.; Hammerich, O., Eds. Marcel Dekker: New York, 2001; pp 499-543. (b) Schäfer, H. J, Recent Contributions of Kolbe Electrolysis to Organic Synthesis. In Topics in Current Chemistry: Electrochemistry IV, Streckhan, E., Eds. Springer, Berlin, 1990, 91-151. (c) Schäfer, H. J, Eur. J. Lipid. Sci. Technol. 2012, 114, 2-9. 
22. (a) Kreh, R. P.; Spotnitz, R. M.; Lundquist, J. T.; Tetrahedron Lett. 1987, 28,1067-1068.

(b) Kreysa, G.; Medin, H. J. Appl. Electrochem. 1986, 16, 757-767. (c) Tzedakis, T.; Savall, A. J. Appl. Electrochem. 1997, 27, 589-597.

23. For reviews on TEMPO: (a) de Nooy, A. E. J.; Besemer, A. C.; van Bekkum, H. Synthesis 1996, 1153-1176. (b) Sheldon, R. A.; Arends, I. W. C. E. Adv. Synth. Catal. 2004, 346, 1051-1071. (c) Ciriminna, R.; Pagliaro, M. Org. Process Res. Dev. 2010, 14, 245-251. (d) Tebben, L.; Studer, A. Angew. Chem., Int. Ed. 2011, 50, 5034-5068. (e) Wertz, S.; Studer, A. Green Chem. 2013, 15, 3116-3134. (f) Ryland, B. L.; Stahl, S. S. Angew. Chem., Int. Ed. 2014, 53, 8824-8838. (g) Cao, Q.; Dornan, L. M.; Rogan, L.; Hughes, N. L.; Muldoon, M. Chem. Commun. 2014, 50, 4524-4543. (g) Seki, Y.; Oisaki, K.; Kanai, M. Tetrahedron Lett. 2014, 55, 3738-3746. For a recent example highlighting the benefit of faster oxoammonium ion reactions: (h) Rafiee, M.; Miles, K. C.; Stahl, S. S. J. Am. Chem. Soc. 2015, 137, 14751-14757.

24. (a) Kuleshova, J.; Hill-Cousins, J. T.; Birkin, P. R.; Pletcher, D.; Brown, R. C. D.; Green, R. A.; Underwood, T. J.; Leach, S. ChemSusChem 2012, 5, 326-331. (b) Green, R. A.; Hill-Cousins, J. T.; Brown, R. C. D.; Pletcher, D.; Leach, S. G. Electrochim. Acta 2013, $113,550-556$.

25. For examples of NHC-mediated electrochemical oxidation in batch reactors: (a) Tam, S. W.; Jimenez, L.; Diederich, F. J. Am. Chem. Soc. 1992, 114, 1503-1505. (b) Finney, E. E.; Ogawa, K. A.; Boydston, A. J. J. Am. Chem. Soc. 2012, 134, 12374-12377. (c) Ogawa, K. A.; Boydston, A. J. Org. Lett. 2014, 16, 1928-1931. For general reviews of oxidative NHC transformations: (d) De Sarkar, S.; Biswas, A.; Samanta, R. C.; Studer, A. Chem. Eur. J. 2013, 19, 4664-4678. (e) Knappke, C. E. I.; Imami, A.; Jacobi von Wangelin, A. ChemCatChem 2012, 4, 937-941.

26. (a) Green, R. A; Pletcher D.; Leach, S. G.; Brown, R. C. D. Org. Lett. 2015, 17, 32903293. (b) Green, R. A; Pletcher D.; Leach, S. G.; Brown, R. C. D. Org. Lett. 2016, 18, 1198-1201. 